\title{
ACADEMIC SELF-CONCEPT AND ACADEMIC SELF-EFFICACY BELIEFS AS CORRELATE OF ACADEMIC ACHIEVEMENT IN ENGLISH LANGUAGE OF SECONDARY SCHOOL STUDENTS IN ANAMBRA STATE, NIGERIA
}

\author{
ANYANWU ADELINE NNE \& EMESI KINGSLEY EKENE \\ Department of Educational Foundations Faculty of Education, Nnamdi Azikiwe University \\ Awka Anambra State
}

\begin{abstract}
Although the issue concerning academic self-concept and self-efficacy beliefs as personality constructs has been vague and their association to determine academic achievement has been nebulous as well. The study aimed to explore the relationship between student's academic self-concept and self-efficacy beliefs in determining secondary school student's academic achievement in the English language in Anambra State. Four research questions and four null hypotheses guided the study. The study adopted a correlational approach to provide answers to the research questions and testing of the hypotheses. The population of the study comprised 21204 from which a sample of 600 was drawn. A multi-stage procedure was used to select the sample. Two standardized research instruments namely; Self-Description Questionnaire (SDQ) and Self-Efficacy Scale (SES), as well as scores from students' promotional examinations were used for data collection. Cronbach's alpha was used to determine the reliability of the items in the instruments. A reliability index of 0.78 , and 0.69 , for academic self-concept and self-efficacy beliefs respectively. The overall reliability coefficient was 0.7 which shows that the instruments were reliable and good for the study. The Pearson Product Moment Correlation was used to answer research questions 1-3 and test hypotheses 1-3 while research question four and hypothesis four were answered and tested with multiple regression. Findings showed that students' academic self-concept recorded a low positive relationship with their self-efficacy beliefs. Findings also reveal that these variables statistically predicted students' academic achievement in the English language. Based on these findings, it was recommended that as students' academic self-concept and self-efficacy beliefs jointly predicted their academic achievement positively, focusing attention on the constant re-orientation of students towards these personality constructs should be encouraged as a panacea to students' disengagement in academic context irrespective of the subject domain.
\end{abstract}

Keywords: Academic self-concept, Self-efficacy beliefs, and Academic Achievement.

\subsection{INTRODUCTION}

Interestingly, educators and researchers in social psychology and educational psychology have devoted much interest in the role of self-related perceptions and their interplay in shaping human development. Individuals who are otherwise similar feel differently about themselves and choose different courses of action, depending on how they construe themselves. This is in relation with the individuals' beliefs that are in a match with what attributes they presume they have peculiarly, such as what they believe they are capable of, how they view themselves in comparison with others, and how they presumed being judged by others (Bong \&Shaalvik, 2013). Without a doubt, these are beliefs and perceptions about the self that are heavily rooted in one's past achievement and reinforcement history. In a historical remark, Bandura, (1997) affirmed that these are subjective convictions about 
oneself and once established, played a determining role in shaping individuals' perception in the environment.

It is reasonable to believe with the study of Byrne (2014) which asserts that these selfperceptions have received a great deal of attention in educational research. Previously, Bong and Shaalvik (2013) opined that children with different self-beliefs demonstrate different levels of cognitive, social, and emotional perception to engage in academic contexts. In the past decades, numerous studies in educational research have resorted to either self-concept or self-efficacy beliefs to explain the function of self in determining academic contexts. On this issue, researchers and educators are interested to understand the distinguishing characteristics and comparative usefulness of students' academic self-concept and self-efficacy beliefs as these constructs may determine academic achievement. It is nonetheless possible to illuminate some of the similarities and differences between these two conceptions as they shape, guide, and determine academic achievement is one of the main theoretical gaps to be closed in this study.

Historically Rosenberg (1979, p.7) colloquially defined the composite view of self-concept as the totality of the individual's thoughts, feelings, and having reference to oneself as an object. This definition has formed the theoretical foundation of contemporary self-concept research that paved way for the emergence of academic self-concept. This shows that self-concept is organized, multifaceted, hierarchical, stable, developmental, evaluative, and differentiable. It is on this view that Valentine, Dubois, and Croper (2014) described academic self-concept as students' self-perception of their academic ability formed through individual experiences and interactions within the school environment. Importantly, academic self-concept is formed and developed through interactions with students' significant others such as parents, teachers, and peers and therefore dynamic as a student progresses through schooling. In another perspective, Emesi (2017) described academic self-concept as an internal personality construct that represents the beliefs and dispositions for one's academic ability. It is interesting to say that the overriding theoretical orientation of human perception is grounded in the perceptual psychology tradition. According to Obilor (2011), perceptual psychologists postulated that all persons create their own reality through their perceptions of what they believe to be real. And that a person's behavior is contingent on how an individual perceives and interprets his/her experiences. Thus, from the perspective of perceptual psychology, it is clear that to understand an individual's behavior, we need to know how that individual perceives and interprets his/her experiences. In relation to Obilors' view, Shavelson, Hubner, and Stanton (2006) as was cited by Anyanwu and Emesi (2019) described academic selfconcept as the totality of the cognitive beliefs that people have developed about themselves, which may represent everything that is known about their academic self. This is to say that it is the mental representation of one's academic ability that forms the internal beliefs system which one has for one's academic ability.

In relation to the above explanations, Rayner and Devis (2018) identified some key antecedents to the formation of academic self-concept such as; frames of reference, causal attribution, reflected appraisals from significant others, mastery experiences, and psychological centrality. Frames of reference deal with the standards against which to judge one's own traits and accomplishments. Causal attributions is the factor to which people attribute their successes and failures that are hypothesized to influence descriptive and affective aspect of their academic self-concept. Reflective appraisals from significant others describe the view people have as they imagine how others view them, i.e., the make-up of reflected appraisals from the significant others. Mastery experience described how selfschemas, is created from an individual's past experiences in a particular domain. Psychological centrality claims that self-concept is based on self-assessments of qualities that are perceived as important or psychologically central by individuals. In other words, to appreciate students' academic achievement, we need to understand how students perceive and 
interpret school and school subjects by investigating their academic belief systems such as academic self-concept and self-efficacy beliefs. Then, the significant roles of education in examining the perceptual ability of the students to engage in academic context will help to facilitate the development of the students' academic self-concept and their self-efficacy beliefs for their association could predict academic achievement.

On the other hand, self-efficacy beliefs as was historically captured by Bandura (1977) is one's capabilities to organize and execute the courses of action required to produce given attainments. Such beliefs influence the course of action people have chosen in pursuing a task, which involves; how much effort they put fort in given endevours, how long they will persevere in the face of obstacles and failures, their resilience to adversity, whether their thought patterns are self-hindering or self-aiding, how much stress and depression they experience in coping with taxing environmental demands, and the level of accomplishments they realize. According to Bong and Skaalvik (2013) self-efficacy beliefs is presumed to explain and predict one's thought, emotion, and action. However, efficacy judgment is less concerned with what skills and abilities individuals possess. It considers more important with what individual believes they can do with whatever skills and abilities they may possess.

This provides a point of comparison with self-concept judgment, which routinely calls for an evaluation of the skills and abilities as they form an integral part that represents one's general perceptions of the self in a given domain of functioning. While self-efficacy beliefs represent individuals' expectations and convictions of what they can accomplish in a given situation. For example, the historical review of Bandura (1997) opined that self-efficacy beliefs are being shaped by the information from the following four major sources such as; enactive mastery experience, vicarious experience, verbal persuasion, and physiological reactions. Enactive mastery experience is one's prior experiences with the tasks in question that provide the most reliable sources of information for efficacy beliefs. Vicarious experience indicates that people establish their self-efficacy beliefs on the tasks. Verbal persuasion deals with persuasive communication and evaluative feedback from significant others as it influences one's judgment of self-efficacy beliefs. Physiological reactions deals with heightened physiological arousal such as sweating, heartbeats, fatigue, aches, pains, and mood changes as this sends the signal to people which affects their efficacy appraisal.

The subtle conceptual distinction between academic self-concept and academic self-efficacy beliefs applies equally to these self-perceptions (Wigfield, \&Karpathian, 2014). This is because both are dealing with the same academic domain. It is conceivably more difficult to identify the critical distinction between these two constructs. Despite the vast volume of evidence attesting to the powerful nature of these personality constructs, it is not always easy to locate specific factors or workable strategies to enhance these beliefs to realize such desirable outcomes. This difficulty is in part due to the hazy distinction between academic self-concept and self-efficacy beliefs, which thwarts any synthesis or integration efforts of the sort.

In an attempt to understand several apparent differences and similarities in assessment procedures, both constructs seem to call for a subjective judgment of perceived competence in reference to some target domain and activities (Bong, 2012). In addition to the cognitive appraisal of one's competence, Zimmerman (2016) indicated that academic self-concept assessment inquires about students' affective reactions to the recognized self and its attributes. On the other hand, in self-efficacy beliefs, respondents make largely cognitive evaluations of their perceived capability without deliberately reflecting on their feelings generated by those evaluations.

The theoretical and operational definitions of the constructs, when compared, also create the impression that academic self-concept embodies fairly stable perceptions of the self that are past-oriented, whereas self-efficacy beliefs represent relatively malleable and future-oriented 
conception of the self and its potential (Zimmerman, 2016). In the context of the present study, the researchers operationally defined academic self-concept as the beliefs, perceptions, and opinions individuals have about themselves which influence their behaviors and consequently affect their achievement in life. The researchers also operationally defined selfefficacy beliefs as the individuals' confidence in themselves to compete, perform, and satisfactorily complete a task, which can have a positive or negative impact, depending on the interpretation of success. It is on this ground that researchers examined the relative contributions of the interplay between students' academic self-concept and self-efficacy beliefs in determining academic achievement.

Interestingly, students' academic achievement is a fundamental priority and concern of all countries. Academic success of students enriches the human resources of the society and guarantees the future development of a country. In contrast, educational failures make communities impossible to use their potential of human capital and endanger sustainable development in addition to great monetary losses (Bahrami\&Bahrami, 2015). This is because preparing individuals to acquire knowledge and skill and training of manpower is the main task of the education system. Importantly, high efficacy and quality of the educational system are among the most influential factors of national development and this could be traceable from the academic achievement of the students. The study of Adeyinka, Adedeji and Olufemi (2011) had described the academic achievement as the attainment of success of a student in his schoolwork among his classmates. Also, Kpolovie, Joe, and Okoto (2014) viewed academic achievement as the ability of the students to study and remember facts and being able to communicate their knowledge orally or in written form even in an examination condition. This shows that academic achievement is a measurable index that depicts a student's cognitive, affective, and creative ability of the students' in educational settings. In addition to that, academic achievement is the observed and measured aspects of a student's mastery of skills and subject contents as measured with valued and reliable tests (Joe, Kpolovie, Osonwa\&Werima, 2014). Then, for the purpose of this study, the researchers operationally defined academic achievement as the overall measure of students' cognitive, social, emotional, and creative outcomes that represent an indication of success or failure in the academic context in any academic domain.

Suffice it to say that many types of research have been carried out to examine the relationship that existed among the three variables of the study. For example, the studies of Obilor (2012) and Obilor (2011) have confirmed a significant relationship between student's academic selfconcept and academic achievement. The study of Anyanwu and Emesi (2019) had recorded a very low positive and significant relationship between student's academic self-concept and their academic achievement. Also, the study ofObi, Onyegirim, Ani, and Ebe (2017) indicated a significant relationship between student's academic self-concept and their academic achievement. The study of Baanu, Oyelekan, and Olorundare (2016) recorded a non-significant relationship between students' self-efficacy beliefs and academic achievement. In the study of Akomolate, Ogumakin, and Fasooto (2013) it was indicated that the relationship between self-efficacy beliefs and academic self-concept empirically and significantly predicted students' academic performance. In another study, Ude (2015) reveals a positive relationship between students' academic self-concept and their academic achievement. The study of Emesi (2017) recorded a very low positive and significant relationship between academic self-concept and academic achievement but does not predict academic achievement. In another study, Oyuga, Raburu, and Aloka (2019) revealed that a significant weak positive relationship existed between students' self-efficacy beliefs and their academic achievement.

Then, as the domain of the English language has recorded abysmal performance from the students over the years, which attracted the concern of education stakeholders in the country has resulted to the investigation of the possible cause of this perennial academic problem. 
Many reasons have been given for this poor performance in students' English language such as; poor teaching skills, poor time management towards the English language, and students' negative attitude towards learning of English language. Despite the improvement on these identified variables, the problems still persist. One begins to think of some other variable that could predict students' achievement in the English language. Such psychological variables are academic self-concept and academic self-efficacy beliefs. The problem is, could the academic self-concept and self-efficacy beliefs jointly predict English language achievement of secondary school students? Also, the paucity of research in examining the relationship between academic self-concept and self-efficacy beliefs to determine students' academic achievement in Anambra had created an avenue for this study. Against this backdrop, the researchers explored the relationship that exists among students' academic self-concept, selfefficacy beliefs, and academic achievement in the English language in Anambra State.

\section{Research Questions}

1. What is the relationship between student's academic self-concept and their selfefficacy beliefs?

2. What is the relationship between student's academic self-concept and their academic achievement in the English language?

3. What is the relationship between students' self-efficacy beliefs and their academic achievement in the English language?

4. What is the proportion of variance between students' academic self-concept and selfefficacy beliefs in predicting their academic achievement in the English language?

\section{Hypotheses}

1. There is no significant relationship between student's academic self-concept and their self-efficacy beliefs.

2. There is no significant relationship between student's academic self-concept and their academic achievement in the English language.

3. There is no significant relationship between students' self-efficacy beliefs and their academic achievement in the English language.

4. The proportion of variance between students' academic self-concept and selfefficacy beliefs in predicting their academic achievement in the English language is not significant.

\subsection{METHOD}

The researchers used a correlational research design and questionnaires to collect data for the study. The population of the study consisted of 21204 is the total number of students in senior Anambra State. A sample size of 600 questionnaires was administered to respondents and collected for data analysis. A multi-stage sampling procedure was used to select the respondents. The procedures for the selection were as follows: In stage one, three education zones were selected from the six education zones in the state by simple random sampling. Then in stage two, from each sampled education zone, one local government area (L.G.A) was selected through simple random sampling given a total of three (3) L.G.As. In stage three, from each sampled L.G.A, 10 schools were randomly selected giving a total of 30 schools. Then, from each of the schools, 20 SSII students were selected for the study using a table of simple random sampling. This gave a total number of 600 students used in the study.

The study adapted two standardized research questionnaires namely, Marsh (1990) SelfDescription Questionnaire (SDQ) and Bandura (1986) Self-Efficacy Scale (SES). The students' achievement scores were obtained from the schools before the start of the administration of the other two instruments. The students' achievement scores in the English language from the state-wide senior secondary one (SS1) promotion examination were obtained from the schools before the administration of the instruments. 
The methods used for validating the instruments were faced and construct validity by the three experts from the Faculty of Education, Nnamdi Azikiwe University Awka. Cronbach's alpha reliability method was used to determine the internal consistency of the items in the research questions such as 0.78 and 0.69 for academic self-concept and academic selfefficacy beliefs respectively. The overall reliability coefficient was 0.74 which shows that the instrument was reliable and good for the study. The Pearson Product Moment Correlation Coefficient was used in answering research questions one to three and testing hypotheses one to three. Multiple regression was used to answer research question four and to test hypothesis four at a 0.05 level of significance. The decision rule for null hypotheses with a P-value higher than 0.05 was not rejected, while the hypotheses with a P-value lower than 0.05 were rejected. The guide for interpretation of correlation results was done in accordance with Okoye (2015). A rough guide for interpreting correlation coefficient values when a large number of pairs of scores have been correlated. The decision rules to interpret the research questions were presented as follows: $r=.00$, no relationship; $r= \pm 0.0$ to \pm 0.2 , very low relationship; $r= \pm 0.2$ to \pm 0.4 , low relationship; $r= \pm 0.4$ to \pm 0.6 , medium relationship; $r= \pm$ 0.6 to \pm 0.8 , high relationship; and $r= \pm 0.8$ to \pm 1.0 , very high relationship.

\subsection{Presentation of Results}

Research Question 1: What is the relationship between student's academic self-concept and their self-efficacy beliefs?

Table 1: Relationship between students' academic self-concept and their self-efficacy beliefs. $(\mathrm{N}=600)$

\begin{tabular}{|l|l|l|}
\hline Variables & Self-efficacy beliefs(r) & Remarks \\
\hline Academic self-concept & .219 & Very low negative relationship \\
\hline
\end{tabular}

The results in table 1 reveals low positive relationship between students' academic selfconcept and their self-efficacy beliefs.

Research Question 2: What is the relationship between students' academic self-concept and their academic achievement in English language?

Table 2: Relationship between students' academic self-concept and their academic achievement in English language. $(\mathrm{N}=600)$

\begin{tabular}{|l|l|l|}
\hline Variables & Academic achievement (r) & Remarks \\
\hline Academic self-confidence & -.049 & medium negative relationship \\
\hline
\end{tabular}

The results in table 1 reveals very low negative relationship between students' academic selfconfidence and their academic achievement in English language.

Research Question 3: What is the relationship between students' academic self-efficacy beliefs and their academic achievement in English language?

Table 3: Relationship between students' academic self-efficacy beliefs and their academic achievement in English language. $(\mathrm{N}=600)$

\begin{tabular}{|l|c|l|}
\hline Variables & Academic achievement (r) & Remarks \\
\hline Academic self-efficacy beliefs & .087 & Very low positive relationship \\
\hline
\end{tabular}


65 | International Journal of Scientific and Management Research 04 (03) 59-70

The results in table 3 reveals very low positive relationship between students' academic selfconfidence and their academic achievement in English language.

Research Question 4: The proportion of variance in academic achievement that is explained by students' students' academic self-concept and their self-efficacy beliefs. $(\mathrm{N}=600)$

\begin{tabular}{|l|l|l|l|l|}
\hline Model & $\mathrm{R}$ & R Square & Adjusted R Square & Std. Error of the Estimate \\
\hline 1 & $.111^{\mathrm{a}}$ & .012 & .009 & 7.31890 \\
\hline
\end{tabular}

Table 4 revealed that the proportion of variance in academic achievement that is explained by students' students' academic self-concept and their self-efficacy beliefs is $1.2 \%$ While R adjusted is .009 with standard error of 7.31890 .

Hypothesis 1: There is no significant relationship between students' academic self-concept and their self-efficacy beliefs.

Table 5. The test for significant Relationship between Students' Academic self-concept and their self-efficacy beliefs. $(N=600)$

\begin{tabular}{|l|l|l|l|}
\hline Variable & Self-efficacy beliefs(r) & P-value & Remark \\
\hline Academic self-concept & .219 & .000 & $\mathrm{~S}$ \\
\hline
\end{tabular}

S-Significant correlation at 0.05 level of significance.

The result in table 5 reveals that there is a significant relationship between students' academic self-concept and their self-efficacy beliefs. $(r=.219>0.05)$.

Hypothesis 2: There is no significant relationship between students' academic self-concept and their academic achievement in English language.

Table 6. The test for significant Relationship between Students' Academic self-concept and their academic achievement in English language. $(N=600)$

\begin{tabular}{|l|l|l|l|}
\hline Variable & English achievement(r) & P-value & Remark \\
\hline Academic self-concept & -.049 & .235 & NS \\
\hline
\end{tabular}

NS-Non-Significant correlation at 0.05 level of significance.

The results in table 6 reveal that there is no significant relationship between students' academic self-concept and their academic achievement in English language. $(r=-.049<0.05)$.

Hypothesis 3: There is no significant relationship between students' self-efficacy beliefs and their academic achievement in English language.

Table 7. The test for significant Relationship between Students' self-efficacy beliefs and their academic achievement in English language. $(N=600)$

\begin{tabular}{|l|l|l|l|}
\hline Variable & English achievement(r) & P-value & Remark \\
\hline Self-efficacy beliefs & .087 & .033 & $\mathrm{~S}$ \\
\hline
\end{tabular}

S-Significant correlation at 0.05 level of significance. 
66 | International Journal of Scientific and Management Research 04 (03) 59-70

The results in table 7 reveal that there is a significant relationship between students' selfefficacy beliefs and their academic achievement in English language. $(r=.087>0.05)$.

Table 8: Multiple Regressions of Students' Academic Self-confidence and their Technological Experience. $(\mathrm{N}=600)$

\begin{tabular}{|c|c|c|c|c|c|c|c|c|}
\hline Model & \multicolumn{2}{|l|}{$\mathrm{R}$} & \multicolumn{4}{|c|}{ R Square } & $\begin{array}{l}\text { Adjusted } \mathrm{R} \\
\text { Square }\end{array}$ & $\begin{array}{l}\text { Std. Error of } \\
\text { Estimate }\end{array}$ \\
\hline 1 & \multicolumn{2}{|l|}{$.111^{\mathrm{a}}$} & \multicolumn{4}{|l|}{.012} & .009 & 7.31890 \\
\hline \multicolumn{3}{|l|}{ Model } & \multicolumn{4}{|c|}{ Change Statistics } & \multicolumn{2}{|r|}{ Sig F Change } \\
\hline & \multicolumn{2}{|l|}{$\begin{array}{l}\text { RSquare } \\
\text { Change }\end{array}$} & \multicolumn{2}{|c|}{ F Change } & \multicolumn{2}{|c|}{ df1 } & df2 & .024 \\
\hline 1 & \multicolumn{2}{|l|}{.012} & \multicolumn{2}{|l|}{3.733} & 2 & & 597 & \\
\hline Model & & & ares & Df & & $\begin{array}{l}\text { Mean } \\
\text { Square }\end{array}$ & $\mathrm{F}$ & Sign \\
\hline 1 & Regression & & .943 & 2 & & 199.972 & 3.733 & $.024^{\mathrm{b}}$ \\
\hline & Residual & & 79.117 & $59^{\prime}$ & & 53.566 & & \\
\hline & Total & & 79.060 & 59 & & & & \\
\hline
\end{tabular}

\begin{tabular}{|l|l|l|l|l|l|}
\hline & $\begin{array}{l}\text { Unstandardized } \\
\text { Coefficients }\end{array}$ & $\begin{array}{l}\text { Standardized } \\
\text { Coefficients }\end{array}$ & & & \\
\hline Model & B & Std. Error & Beta & T & Sig. \\
\hline 1 (Constant) & 45.865 & 2.455 & & 18.685 & .000 \\
\hline $\begin{array}{l}\text { Academic self- } \\
\text { concept }\end{array}$ & -.064 & .037 & -.071 &.-1.703 & .089 \\
\hline $\begin{array}{l}\text { Self-efficacy } \\
\text { beliefs }\end{array}$ & .092 & .038 & .102 & 2.458 & .014 \\
\hline
\end{tabular}

The table shows a multiple regression run to predict students' academic achievement from academic self-concept and their self-efficacy beliefs. These variables statistically predicted the academic achievement of the students, F $(2,597)=3.733$, with an R2 of $1.2 \%$. Students' academic self-concept and self-efficacy beliefs statistically predicted academic achievement, $\mathrm{P}>.05$. The results in the table also revealed the relative contribution of each variable, however, revealed that academic self-efficacy beliefs are the most potent predictor of students' academic achievement than the other variable $(\beta=.038, \mathrm{t}=2.458, \mathrm{p}=.014)$. The findings further showed that academic self-concept is significant in predicting students' academic achievement. Conclusively, the null hypothesis was rejected, then it was concluded that students' academic self-concept and self-efficacy beliefs significantly predicted their academic achievement in the English language.

\subsection{DISCUSSION}


Findings in Table 1 reveal a low positive relationship between students' academic selfconcept and their self-efficacy beliefs. This supported the study of Akomolate et al (2013) which recorded a positive relationship between students' academic self-concept and their self-efficacy beliefs.

Findings in Table 2 reveal a very low negative relationship between students' academic selfconcept and their academic achievement in the English language. The study of Obi et al (2017) supported the present study as it recorded a low negative relationship between students' academic self-concept and their academic achievement in the English language. This does not support the study of Dramanu andBalarabe (2013) which recorded a positive relationship between students' academic self-concept and their academic performance. The present findings do not support Ude (2015) that recorded a positive relationship between students' academic self-concept and their academic achievement. The findings do not support the study of Emesi (2017) which indicated a very low positive relationship between students' academic self-concept and their academic achievement.

Findings in Table 3 reveal a very low positive relationship between students' self-efficacy beliefs and their academic achievement in English language. This supported the study of Oyuga et al (2019) which recorded a weak relationship between students' self-efficacy beliefs and their academic achievement. Findings in Table 4 reveals a low percentage in explaining the proportion of variance in academic achievement in the English language that is explained by students' academic self-concept and self-efficacy beliefs.

The findings in table 5 reveal a significant relationship between student's academic selfconcept and their self-efficacy beliefs in predicting student's academic achievement in the English language. This supported the study of Oyuga et al (2019) which recorded that students' academic self-concept and self-efficacy beliefs significantly predicted academic achievement.

Findings in Table 6 reveal that the relationship between student's academic self-concept and there is not significant. This does not support the study of Emesi (2017) which recorded a significant relationship between student's academic self-concept and their academic achievement is significant. Also, the study of Obilor $(2012,2011)$ does not support the present study as each recorded a significant relationship between student's academic selfconcept and their academic achievement respectively. The study of Anyanwu and Emesis does not support the present study as it recorded that students' academic self-concept was significantly related to academic achievement. The study of Obi et al (2017) does not support these findings as it indicated that there was a significant relationship between students' selfconcept and their academic achievement.

Findings in Table 7 reveal that students' self-efficacy beliefs were significantly related to academic achievement. This does not support the study of Baanu et al (2016) which indicated that there was no significant relationship between students' self-efficacy beliefs and their academic achievement. Also, the study of Balami (2016) does not support the present study's findings as it recorded that the relationship between students' self-efficacy beliefs and their academic achievement was not significant.

Findings in Table 8 reveal that students' academic self-concept and their self-efficacy beliefs jointly predicted students' academic achievement. This was supported by the study of Akomolate et al (2013) as it recorded that students' academic self-concept and self-efficacy beliefs jointly predicted students' academic achievement. Also, in terms of the magnitude of contribution, self-efficacy beliefs have the highest proportion in explaining the predictive strengths of the variables in determining academic achievement in the present study. This supported the study ofAkomolate et al (2013) as it recorded that self-efficacy beliefs have the highest predictive strength in determining academic achievement. 


\subsection{CONCLUSION}

The results of the study reveal that a very low positive relationship had existed between students' academic self-concept and self-efficacy beliefs. the proportion of variance in academic achievement that was explained by students' academic self-concept and selfefficacy beliefs is low in percentage rating. The multiple regression runs to predict students' academic achievement from academic self-concept and self-efficacy beliefs statistically predicted students' academic achievement in the English language. Therefore, for any secondary institution in Nigeria to advance academically, the imperative issues that bother on these personality constructs such as academic self-concept and self-efficacy beliefs as they normally contribute to the development of students' academic potentialities need to be thoroughly addressed, through collective orientation and motivational talks to enable students' to hold and maintain good academic self-concept and self-efficacy beliefs.

\subsection{RECOMMENDATIONS}

Based on the findings, the following recommendations were made.

1. Given the significance of academic self-concept and self-efficacy beliefs in determining the academic achievement of students, the enhancement of these personality constructs should be a major concern for educators, program developers, teachers, and counselors.

2. With the findings from the study, personality construct development should be made a central focus on educational policymaking in Nigeria as this will facilitate the transformation of the students' beliefs systems towards academic engagement.

3. As the findings had recorded a very low positive relationship among the study of the variables, the aim of the education system must transcend the development of academic competence through enhancing the students' academic self-concept and self-efficacy beliefs for this will make the students endorse positive dispositional preferences towards academic context.

4. Having recorded a very low relationship between students' academic self-concept and self-efficacy beliefs in predicting academic achievement, schools should be added with the responsibility of preparing the students to become self-assured and fullyfunctioning individuals capable of pursuing their academic hopes and their academic ambitions.

5. Counseling services should be provided in schools so that students having problems in academic subject domains can be attended to through the combined efforts of the school and home as this will nurture the development of students' academic selfconcept and self-efficacy beliefs.

6. Despite the fact that the association between academic self-concept and self-efficacy beliefs has been an issue of debate in the field of research, more researches on these fields of personality constructs should be conducted to explore the nature of interactions of these constructs and how they impact on academic achievement, vocational choice and problem-solving abilities on the students.

7. This study should be repeated by other researchers with another population to explore the various facets of academic self-concept and self-efficacy beliefs for this will help to bring more approaches that will enable the students to demonstrate high level cognitive, social, and emotional perception to engage in academic contexts by using different academic domains and institutions.

8. As the findings finally reveal that students' academic self-concept and self-efficacy beliefs, jointly predicted their academic achievement positively, focusing attention on the constant re-orientation of students towards these personality constructs should be encouraged as a panacea to students' disengagement in the academic context irrespective of the subject domain. 
69 | International Journal of Scientific and Management Research 04 (03) 59-70

\section{REFERENCES}

Adeninka, T., Adedeji, T. \&Olufemi (2011). Locus of control, interest in school and selfefficacy as predictors of academic achievement among junior secondary school students in Osun State, Nigeria. New, Horizons in Education, 59 (1), 25-35.

Akomolate, M. J., Ogunmakin, A. O., \&Fosooto, G.M. (2013). The role of academic selfefficacy, academic motivation and academic self-concept in predicting secondary school students' academic performance. Journal of Educational and Social Research, 3(2), 335.

Anyanwu, A. N \&Emesi K. E. (2019). Relationship among secondary school students' academic self-concept, self-esteem and academic achievement in mathematics in Anambra State. Unizik Journal of Educational Research and Policy Studies, 1 (1), 114-116.

Balami, Y .G. (2015). Relationship between self-efficacy and academic achievement of distance learners in National Teachers Institute (NTI) Adamawa state, Nigeria. International Journal of Educational Psychology and Practices, 3 (2), 80-84.

Baanu, T. F., Oyelekan, O. S., \&Olorundare, A. S. (2016). Self-efficacy and chemistry students' academic achievement in senior secondary schools in North-Central, Nigeria. The Malaysian Online Journal of Educational Science, 2(1), 43-45.

Baharami, D. \&Baharami, M.A (2015). Correlation of self-esteem and achievement goals. The Case of Iranian students. World Applied Science Journal, 33 (4), 557-563.

Bandura, A. (1977). Self-efficacy: Towards a unifying theory of behavoural change. Psychological Review, 84, 199-215.

Bandura, A. (1986). Social foundations though and action: A social cognitive theory. Englewood Cliffs, NJ: Prentice Hall.

Bandura, A. (1997). Self-efficacy. The Exercise of Control. New York: Freeman.

Bong, M. (2012). Predictive utility of subject-task-and problem-specific self-efficacy judgments for immediate and delayed academic performances. Journal of Experimental Education, $\quad 70,133-162$.

Bong, M., \&Skaalvik, E. M. (2013). Academic self-concept and self-efficacy. How different are they really? Educational Psychology Review 15 (1), 1-40.

Byrne, B. M. (2014). The general self-concept technology network: A Review of Constant Validation Research. Review of Educational Research, 54, 427-456.

Emesi, K. E. (2017). Relationship among secondary school students' achievement goal orientation, academic self-concept and academic achievement in mathematics in Anambra State. Unpublished master's thesis.

Joe, A. N., Kpolovie, P. J., Osonwa, K. E., \&Werima, C. E. (2014). Modes of admission and academic achievement in Nigerian Universities. Retrieved from http://meritresearcherjuornals.or/er/content/2014/Pkolovie\%20et\%20al.pdf.

Kpolovie, P. J., Joe, A. N., \&Okoto, T. (2014). Academic achievement prediction: Role of interest in learning and attitude towards school. National Journal of Humanities, Social Science and Education, 11 (1), 73-100. 
Marsh, H. W. (1990). Self Description Questionnaire (SDQ) II: A theoretical and empirical basis for the measurement of multiple dimensions of adolescent self-concept: An interim test manual and a research monograph. San Antonio Texas: The psychological corporation.

Obi, A., Onyegirim, B. O., Ani., D. N., \&Ebe, K. N. (2017). Relationship between students' and self-concept, and their academic achievement in English language in Enugu State, Nigeria. International Journal of Education, Development, Society and Technology, 5 (15), 151-158.

Obilor, I. E. (2011). Influence of academic self-concept on English language and mathematics achievement of senior secondary students in Port Harcourt. The Journal of Educational Psychologist, 6 (1), 104-110.

Obilor, I. E. (2011). Relationship between self-concept and mathematics achievement of senior secondary students in Port Harcourt metropolis. Journal of Educational and Social Research, 1 (4), 39-44.

Okoye, R. (2015). Educational and psychological measurement and evaluation (second edition): Awka, Erudition publisher

Oyuga, P.A., Raburu, P. A., \&Aloka, P .D (2019). Relationship between self-efficacy and academic performance among orphaned secondary school students in Kenya. International Journal of Psychology and Behavioural Sciences, 9 (3), 39-46.

Rayner, S. G., \&Devis, U. (2018). Self-esteem and self-perceptions in the classroom: valuing circle time? In: Riding, R. J., and Rayner, S. G. (eds.). International Perspective on Individual Differences, 2: Self Perception, Ablex, Westport, CO. pp.171-208.

Rosenberg, M. (1979). Society and the adolescent self-image. Princeton, New Jersy: Princeton University Press.

Shavelson, R. J., Hubner, J., \& Stanton, G. C. (2006). Self-concept: Validation of construct interpretations. Review of Educational Research, 46, 407-441.

Ude, V. C. (2015). Relationship between academic self-concept and senior secondary students achievement in Biology. department of Science and Vocational Education, Godfery Okoye University, Enugu, Nigeria.

Valentine, J. C., Dubois, D. L., Copper, H. (2014). The relations between self-beliefs and academic achievement: A systematic review. Educational Psychology, 39, 111-133.

Wigfield, A.. \&Karpathian, M. (2014). Who am I and what can I do? Children's self-concepts and motivation in achievement solutions. Educational Psychologist, 26, 233-261.

Zimmerman, B. J. (2016). Self-Efficacy: An essential motive to learn. Contemporary Educational Psychology, 25, 82-91. 